\title{
Contributions to reduce the flood problems in critical points of the micro drainage system in the city of Carazinho
}

\section{Contribuições para redução dos problemas de alagamento em pontos críticos do sistema de microdrenagem no município de Carazinho}

\author{
Carolina Pasquetti Koppe' \\ Vinicius Scortegagna" \\ Virgínia Meneguzzill' \\ Anelise Sertoli Lopes Gil ${ }^{\mathrm{V}}$ \\ Matheus De Conto Ferreirav \\ Simone Fiorivl \\ Vera Maria Cartana Fernandes $\mathrm{VII}$
}

\begin{abstract}
With the emergence of excessive flooding in the urban environment, the need for unconventional drainage control measures within the limitations of conventional solutions becomes evident. In the present study, infiltration trenches and reservoirs that collect and reserve rainwater were designed as control devices, attenuating the socio-environmental impacts caused by waterproofing of urban areas in the hydrological cycle and in the behavior of the hydrographic basins in question. The measurements were made for two flooding points found in the city of Carazinho - RS, located on Marquês do Pombal Street and São Bento Avenue, due to the obstruction of gutters and street inlets, paving and waterproofing of the ground due to urbanization, lack of maintenance and cleaning of the micro drainage system along with the inability of the system to collect all the volume of water from the runoff. The reductions in flow rate in these areas through the use of trenches were $16 \%$ and $15 \%$ for the first and second flooding point, respectively, while the use of the delay reservoirs together with the infiltration trenches resulted in a $29 \%$ reduction in the first flooding point and $27.5 \%$ in the second flooding point. Therefore, it is evident that the use of unconventional control measures is vital to the reduction of the peaks of the flow rate and control of the surface runoff.
\end{abstract}

Keywords: Urbanization; Urban Drainage System; Conventional Drainage Measures

\footnotetext{
' Eng. Civil, FEAR, Universidade de Passo Fundo, Passo Fundo, RS, Brasil - carolina.p.koppe@gmail.com

" Mestre, FEAR, Universidade de Passo Fundo, Passo Fundo, RS, Brasil - viniciuss@upf.br

III Graduanda em Eng. Civil, FEAR, Universidade de Passo Fundo, Passo Fundo, RS, Brasil vimeneguzzi@hotmail.com

Iv Mestre, FEAR, Universidade de Passo Fundo, Passo Fundo, RS, Brasil - anelise.sertoli@upf.br

$\checkmark$ Mestre, FEAR, Universidade de Passo Fundo, Passo Fundo, RS, Brasil - matheusferreira@upf.br

VI Doutor, FEAR, Universidade de Passo Fundo, Passo Fundo, RS, Brasil - sfiori@upf.br

VII Doutor, FEAR, Universidade de Passo Fundo, Passo Fundo, RS, Brasil - cartana@upf.br
} 


\section{Resumo}

Com o surgimento de exorbitantes alagamentos no meio urbano, torna-se evidente a necessidade de se obter medidas de controle de drenagem não convencionais, em meio às limitações relacionadas às soluções convencionais. No presente trabalho foram dimensionadas trincheiras de infiltração e reservatórios de retardo como dispositivos de controle, atenuando os impactos socioambientais causados pela impermeabilização das áreas urbanas no ciclo hidrológico e no comportamento das bacias hidrográficas em questão. Os dimensionamentos foram realizados para dois pontos de alagamento do município de Carazinho - RS, localizados na Rua Marquês do Pombal e na Avenida São Bento, decorrentes da obstrução de sarjetas e bocas de lobo, pavimentação e impermeabilização do solo devido à urbanização, falta de manutenção e limpeza do sistema de microdrenagem e da incapacidade do sistema de coletar todo o volume de água do escoamento superficial. As reduções nas vazões nessas áreas através da utilização das trincheiras foram de $16 \%$ e $15 \%$ para o primeiro e o segundo ponto de alagamento, respectivamente, enquanto o uso dos reservatórios de retardo conjuntamente com as trincheiras de infiltração provocou uma redução na vazão de $29 \%$, no primeiro ponto de alagamento, e de $27,5 \%$ no segundo ponto de alagamento. Dessa forma, torna-se evidente a eficiência do uso das medidas de controle não convencionais a favor da redução dos picos de vazão e controle do escoamento superficial.

Palavras-chave: Urbanização; Sistemas de Drenagem Urbana; Medidas de Drenagem Convencionais 


\section{Introduction}

With the increasing urbanization process that has become more rapid since 1950, the natural phenomena of floods are interrupted by human settlements which cause changes and increase the risks associated with them (PONTE et al., 2014). Thus, with the lack of urban planning, this occupation occurred with an inadequate infrastructure. This generates a series of environmental and social problems, such as the occupation of riparian areas and the waterproofing of the watershed, caused by the paving of large areas and the construction of buildings, resulting in decreased soil retention and infiltration capacity. This waterproofing of large areas causes a change in the natural water balance, generating a large increase in the surface runoff and drastic changes in rainwater hydrographs observed in the occupied river basin.

The increase in the surface runoff results in urban floods in conjunction with a poorly planned urbanization process that is characterized by poor land use, occupation of risk areas, inefficiency along with lack of maintenance of public drainage systems and failures in the processing of waste collection and disposal (REIS et al., 2008).

Although the flood is a natural phenomenon of the river regime that is characterized by the elevation of the water level caused by the increase of the flow rate, reaching the maximum quota without extravasation, and even though every river has its area of flood, that is, when a watercourse overflows reaching marginal areas (PINTO and PINHEIRO, 2006), the frequency and severity of floods show that the traditional drainage systems adopted become insufficient as the occupation of the river basin intensifies.

Thus, the conventional drainage system currently used in most Brazilian cities is insufficient, since it aims to quickly drain the water from precipitation, thus transporting the drainage problem to a point downstream, resulting in more extensive galleries. As a consequence, unconventional drainage measures should be taken in order to solve the problem without transferring it elsewhere. 
Nevertheless, the city of Carazinho located in the northern region of the Brazilian Rio Grande do Sul State is located at a point considered as a watershed and it is inserted in two hydrographic regions. According to the Municipal Basic Sanitation Plan of 2015 (PMSB), the northwest region of the urban area of the city is inserted in the Uruguay Hydrographic Region, Basin of the Várzea River. Regarding the southeast region of the urban area of the municipality, it is in the Guaíba Hydrographic Region, Upper Jacuí Basin. The watershed considered by the PMSB is Flores da Cunha Avenue, the main street of the city.

The micro drainage system of the city consists of galleries built on concrete pipes and curb-opening inlets. On the other hand, the macro drainage system is composed of streams and rivers that pass through the city. As for the flooding problems in the city due to more intense rainfall, these are temporary and caused by the obstruction of gutters and street inlets as a result of improperly discarded solid waste, paving and waterproofing of the ground attributable to urbanization, lack of maintenance and cleaning of the micro drainage system and also to the inability of the system to collect the entire volume of water from the surface runoff.

Therefore, urban drainage now requires a more sustainable approach to be effective. In this way, solutions are sought for the infiltration of precipitated water in the soil or its detention in order to reduce the volume of precipitation drained in the gutters and galleries. This would create points that allow the recharge of aquifers, besides reestablishing the natural water balance and reduce the occurrence of floods, as well as consequently minimizing the impacts that the waterproofing causes to the environment and to the population.

In the present work, it is presented a study based on the field survey at critical points of flooding caused by rainfall in the city of Carazinho, located in the northern region of the Rio Grande do Sul State which has 62,193 inhabitants and is $665,092 \mathrm{~km}^{2}$ (IBGE, 2016). Thus, the present study is justified by the need to seek other solutions to urban drainage, in order to combine these systems and to mitigate the socioenvironmental impacts caused by the impermeabilization of urban areas in the hydrological cycle and in the behavior of the river basins. Therefore, it was sought to 
verify the possibility of the application of unconventional drainage measures and their effectiveness based on some districts of the city of Carazinho which present problems of flooding. So, the study was developed in the Centro District on Marquês de Pombal Street and in the Floresta District on São Bento Avenue.

\section{Methodology}

The existing topography, carrying out the analysis of the Municipal Plan of Basic Sanitation and the Manual of Drainage of other municipalities, and studies of available literature were all considered. After the diagnosis of the existing micro drainage system, checking the quantity and types of street inlets, the height of the curb, the existence or not of gutters, the type of pavement and the transversal profile of the road, the evaluation of the control measures for each location was carried out. The hydraulic capacity of the street inlets existing in the drainage system of one of the chosen sites which has a mapping of them in the Municipal Basic Sanitation Plan was verified. In addition, the design of the unconventional measures chosen, that is, of the infiltration trenches and the reservoir to collect and reserve rainwater, was also accomplished.

In the final stage of the study, the effectiveness of the use of unconventional along with the conventional measures in the drainage system was verified, taking into account the feasibility of application. This comparison was made by plotting the surface runoff hydrograms directly from each area. In addition, problems were identified in the micro drainage system of the municipality that are possibly contributing to the emergence of flooding points. These include obstruction of the street inlets by the deposit of solid waste with an incorrect disposition, lack of maintenance of the system, lack of design of the micro drainage system of the city and the undue occupation of the river banks that cross the city.

The development of the research method was better presented in the flowchart of Figure 1. 
Figure 1 - Flowchart of the developed method

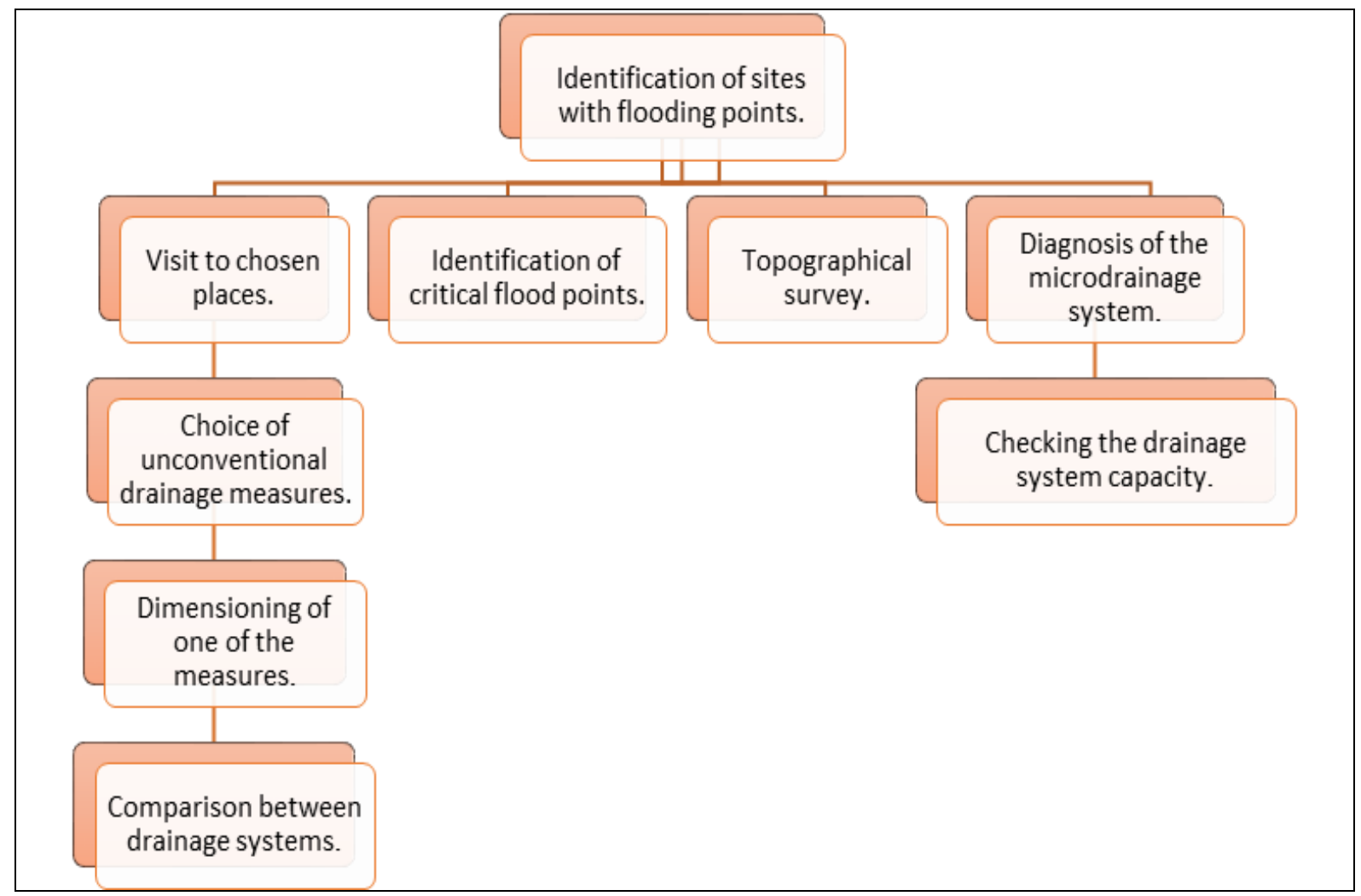

Source: Own elaboration (2016)

\section{Results and Discussion}

\subsection{Diagnosis of the Micro drainage System}

The micro drainage system in one of the survey sites chosen for the study, located on Marquês do Pombal Street in the Center District, has five grated inlets and two curb-opening inlets, as well as two combined street inlets. The dimensions of these street inlets vary widely and many of them are in poor conservation status, as well as partially obstructed by solid waste.

The type of pavement existing in the place is parallelepiped, with the exception to the street perpendicular to the flooding point, Ernesto Alves Street which is asphalted. The height of the curb varies between $10 \mathrm{~cm}, 12 \mathrm{~cm}, 15 \mathrm{~cm}$ and $20 \mathrm{~cm}$ in the different streets and the walkways has a standardized width of 2 meters.

Figure 2 shows the flooding point at the Marquês do Pombal Street and one of the street inlets in precarious conditions found on the site. 
Figure 2 - Photographic records at the first flooding point

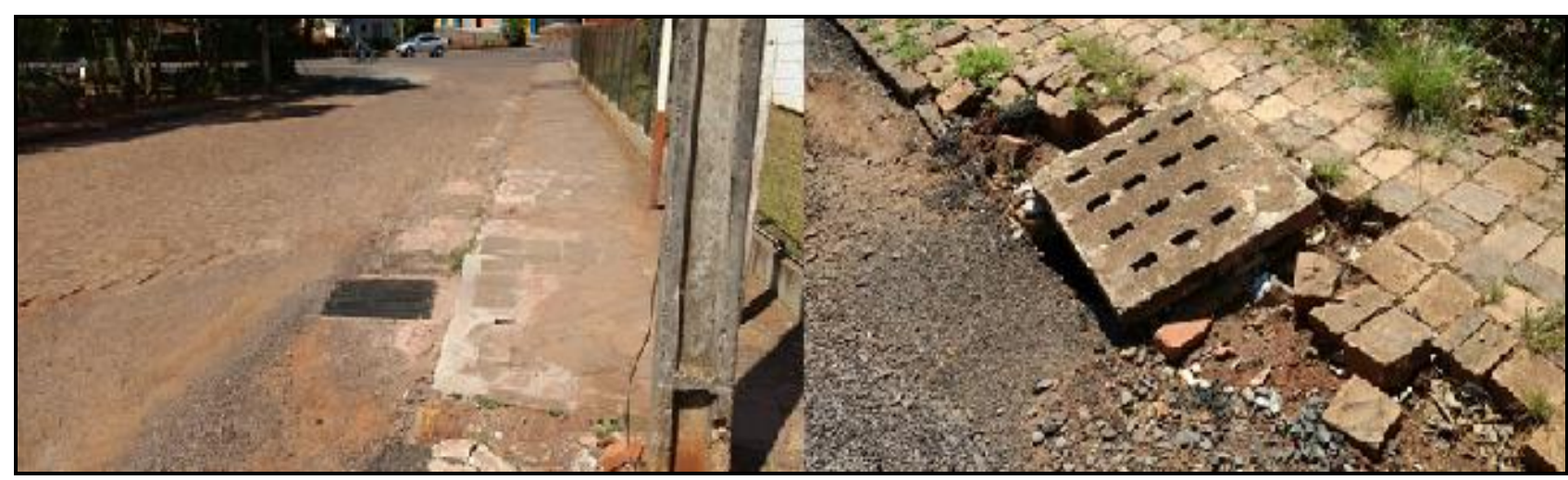

Source: Own elaboration (2016)

The second flooding point under study in the present work is located on São Bento Avenue, near the intersection with Monte Alegre Street in the Floresta District. The area of contribution to the emergence of this flooding point has two different street inlets: curb-opening inlets and grated inlets. The curb-opening inlets only exist on Florianópolis Street, so the type of the street inlet that prevails in this area is the grated inlet. However, they are partially obstructed by vegetation, thus demonstrating the lack of maintenance in the drainage system and, consequently, compromising the hydraulic capacity of the street inlet and the drainage system as a whole. Most of the grated inlets have dimensions of $60 \mathrm{~cm}$ by $60 \mathrm{~cm}$, being distributed mainly in the corners, but in some cases, they are located in the middle of the blocks. Nevertheless, they are in poor condition and obstructed by solid waste discarded incorrectly by the population.

Furthermore, there are three types of pavement surface present in the streets that form the study area: parallelepiped, asphalt and macadamized way. Only São Bento Avenue, Monte Alegre Street, and Florianópolis Street are paved with asphalt. Figure 3 shows the flooding point on São Bento Avenue and one of the street inlets found on the site, obstructed by solid wastes and in precarious conditions. 
Figure 3 - Photographic records at the second flooding point

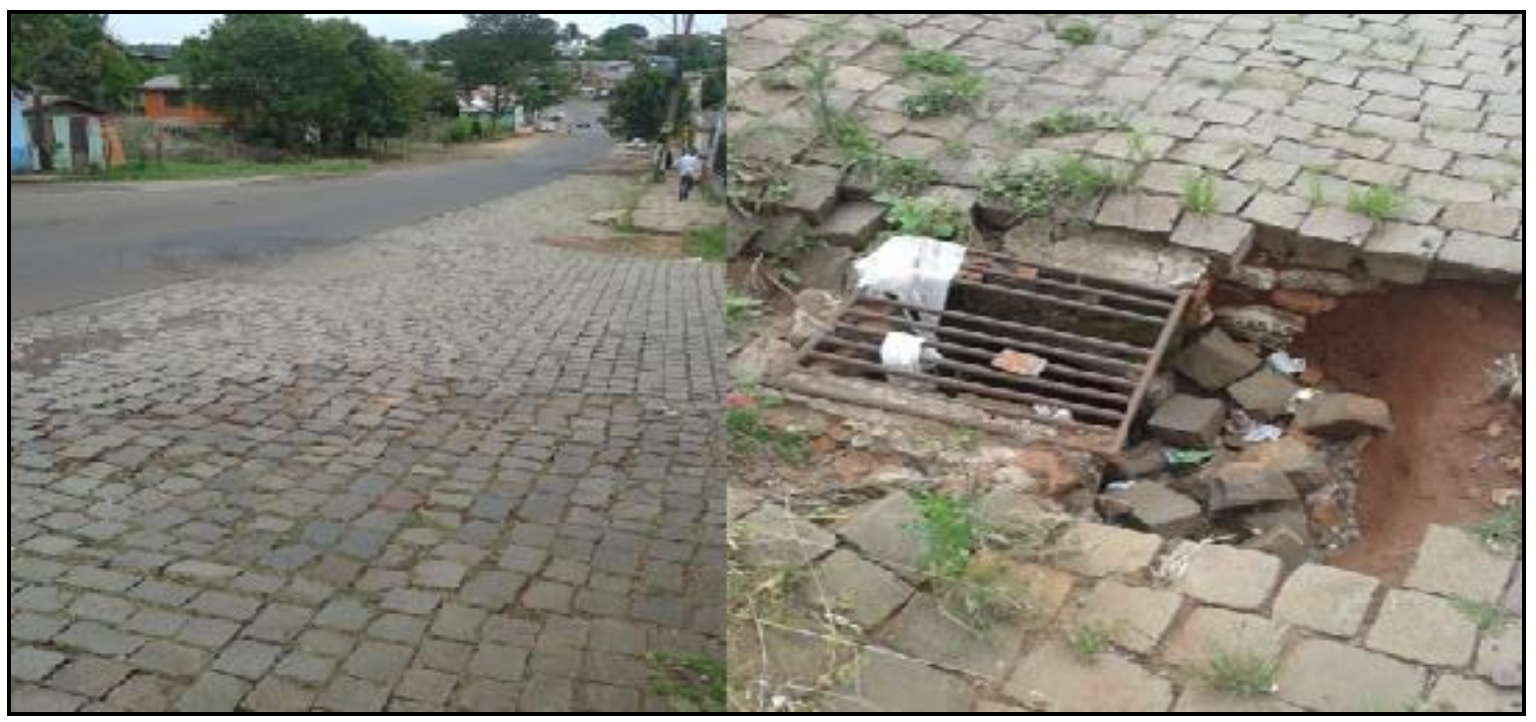

Source: Own elaboration (2016)

\subsection{Choice of the Unconventional Control Measures}

Due to the conditions found in the places where there is occurrence of flooding, such as the available space for the implantation of some unconventional drainage, infiltration trenches were chosen which consist of a lateral drainage device. They are generally used parallel to the streets and the reservoirs that collect and reserve rainwater. These solutions were chosen due to the feasibility of the execution of the reservoirs that collect and reserve rainwater in the front indents of the buildings and of the trenches along the routes, exploring the sidewalks and the middle third of the road, and depending on the possible interferences of other infrastructure systems. Therefore, in order to determine the sizing of the drainage control devices, it was necessary to identify and delimit the areas contributing to the emergence of flooding points in the chosen sites. Thus, the values found for the contribution areas at the flooding points in the Centro and Floresta Districts are 18.3 ha and 24.5 ha, respectively.

Analyzing Figure 5, it can be concluded that it is necessary to distribute the trenches through the various routes, that is, several trenches of different dimensions are required which together must meet the needs of the area. 
Figures 4 and 5 present the contribution areas for each flooding point chosen for the study, delimited in red line, with flooding points highlighted in the red area.

Figure 4 - Area of contribution of the flooding point on Marquês do Pombal Street

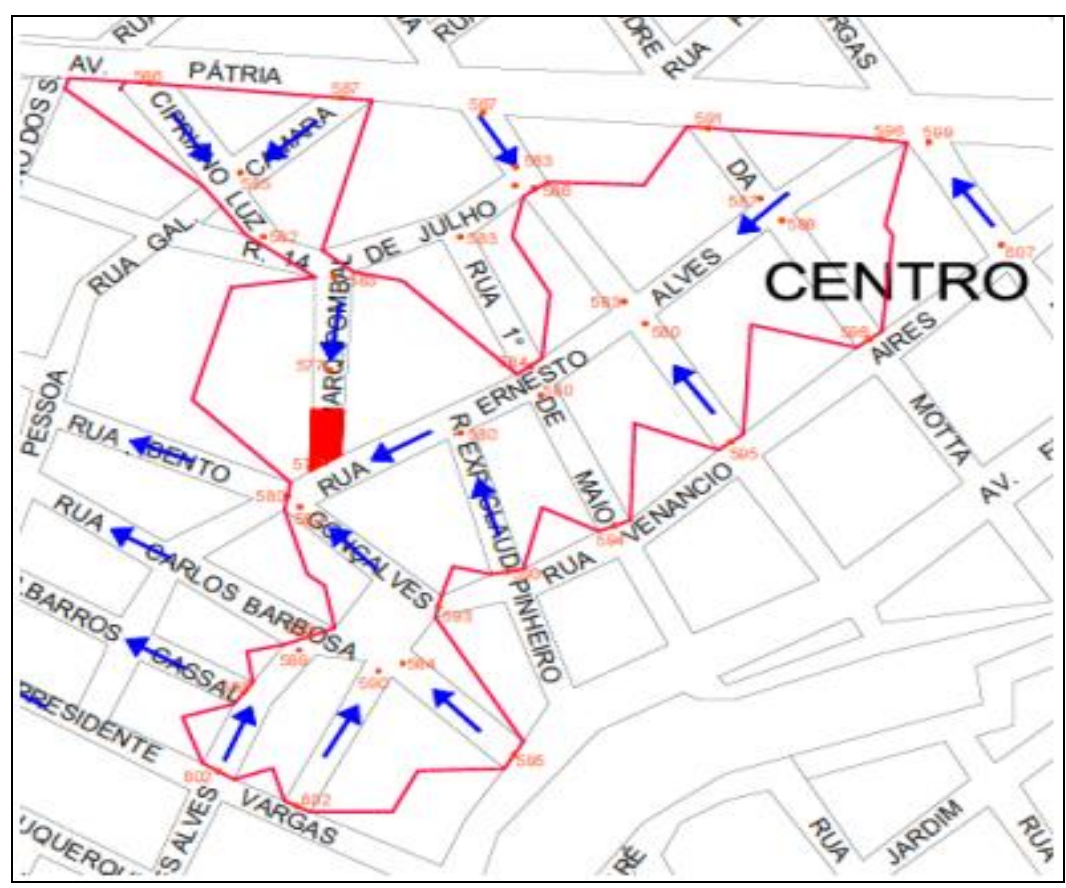

Source: Own elaboration (2016)

Figure 5 - Area of contribution of the flooding point on São Bento Avenue

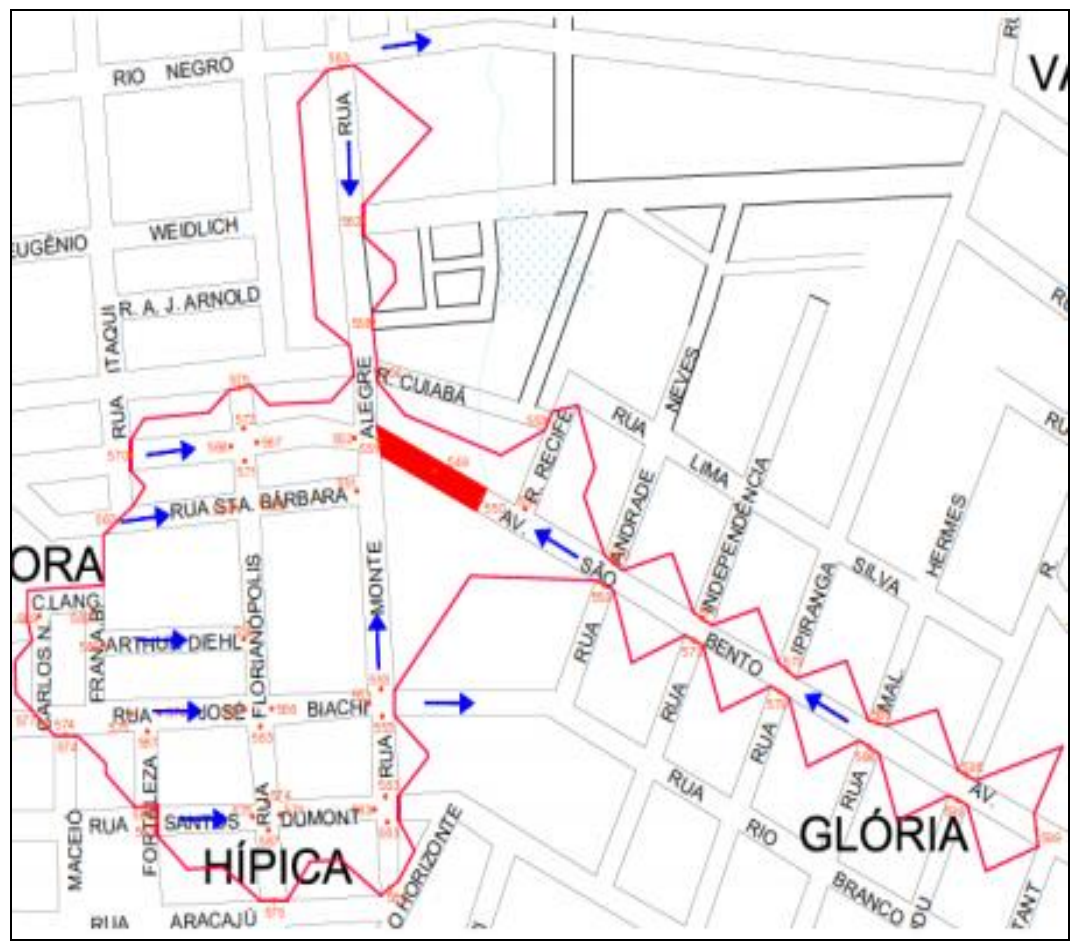

Source: Own elaboration (2016) 
According to Caputo (2012), the success of adopting alternative drainage control measures depends on a thorough analysis of the adaptability to the conditions in each site and the correct design decision, which is the choice of measurement, sizing and possibility of simulate the operation of these measures in different contexts.

The different types of control measures have both strengths and weaknesses according to their application, and the limitations of these structures are in many cases due to the physical characteristics of the site of implantation, risk of contamination of the water table, cost, maintenance need, hydrological characteristics, climate, and others.

Thus, the implementation of unconventional control measures presents certain risks - although the innumerable benefits are visible- such as operation and maintenance which when not appropriate from the beginning may result in a reduction of the effectiveness of the purpose that the control measure was designed. Therefore, the choice of a type of system undergoes a global analysis, in which aspects such as urbanization, existing infrastructure in the locality, costs and, evaluation of the fulfillment of the criteria necessary for the good functioning of the devices are considered.

\subsection{Infiltration Trench Sizing}

The method chosen to carry out the trenches sizing was the Rain-envelopemethod, a method that uses the direct application of characterization data of the implantation site of the infiltration device and of the IDF curve. It is based on the determination of accumulated inflow and outflow volumes of the infiltration trench. According to the Prefeitura de Porto Alegre (2005), "the volume of the device should be sufficient to store the maximum difference between the accumulated volumes of entry and exit (taking into account the porosity of the filling material)."

Therefore, the material chosen for the present study was gravel, which is abundantly available in the region having an effective porosity of $30 \%$ as shown in Table 1. 
Table 1 - Effective porosity of filling materials

\begin{tabular}{lc}
\hline \multicolumn{1}{c}{ Material } & $\begin{array}{c}\text { Effective } \\
\text { Porosity (\%) }\end{array}$ \\
\hline Gravel & 30 \\
\hline Gravel of uniform granulometry & 40 \\
\hline Graduated brita (less than 1/4") & 30 \\
\hline Sand & 25 \\
\hline
\end{tabular}

It was adopted 5 years as the return period in all calculations, since the flooding points are located in urbanization sites that have not yet been fully consolidated, and this value can be suggested in the bibliography for the planning of micro drainage systems.

For the flow coefficient $(C)$, the theory of the method chosen for the sizing of the trenches indicates values between 0.85 and 0.95 . These values are conservative and are indicated for areas where urbanization is already consolidated, which is not the case of the study sites. At the flooding point on Marquês do Pombal Street, the environment is in a phase of transformation where the area ceases to be only residential and starts to count on public buildings and law offices. Consequently, it becomes more urbanized, even though the predominance is of low buildings. At the flooding point on São Bento Avenue, the taxpayer area is still predominantly residential with no fully consolidated urbanization.

In this way, a reduction in the value of the flow coefficient was chosen, and the value used for both cases in all calculations is equal to 0.60 . The main source of consultation for the sizing parameters was the Porto Alegre Drainage Manual, which also shows tabulated values for soil hydraulic conductivity $\left(1 / \mathrm{m}^{2}\right.$.day) already transformed into infiltration coefficients $(\mathrm{mm} / \mathrm{h})$, considering some soil types, classifying them from $A$ to $D$ and separating them based on the soil texture. Thus, the values found were $2.7 \mathrm{~mm} / \mathrm{h}$ or $3.53 \times 10^{-6} \mathrm{~m} / \mathrm{s}$, considering that the soil of the municipality is a type B soil, according to the description in the Porto Alegre Drainage 
Manual (2005): "soils less permeable than the previous one, sandy soils less deep than type A and with higher than average permeability."

\subsection{Sizing of the first flooding point - Marquês do Pombal Street}

The sizing of the flooding point was carried out, firstly, without the application of the reduction factor for the saturated hydraulic conductivity of the soil and with the data presented in Table 2. Moreover, the final dimensions obtained in order to obtain a volume value $\left(\mathrm{V}_{\text {dim }}\right)$ near the value of the trench volume $(\mathrm{VT})$ are shown in Table 3.

Table 2 - Trench dimension data

\begin{tabular}{lc}
\hline \multicolumn{2}{c}{ Data } \\
\hline Basin contribution area (ha) & 18.3 \\
\hline Flow coefficient & 0.6 \\
\hline $\begin{array}{l}\text { Saturated hydraulic } \\
\text { conductivity - k (m/s) }\end{array}$ & 0.00000353 \\
\hline Reduction Factor & 2 \\
\hline k reduced (m/s) & $1.765 \mathrm{E}-06$ \\
\hline Return period (years) & 5 \\
\hline Porosity & 0.3 \\
\hline
\end{tabular}

Table 3 - Dimensions of the trench

\begin{tabular}{lc}
\hline \multicolumn{2}{c}{ Estimated Dimensions } \\
\hline Length $(\mathrm{m})$ & 6000 \\
\hline Width $(\mathrm{m})$ & 1 \\
\hline Height $(\mathrm{m})$ & 2.5 \\
\hline
\end{tabular}

Width of $1 \mathrm{~m}$ and height of $2.5 \mathrm{~m}$ were adopted because these dimensions are compatible with the walkways and if necessary, due to the physical interference of the place, they can also be executed in the middle third of the track, that is, in the next 
track to the curb in the canopy. Thus, with these values, it was reached the percolation area and the trench volume values shown in Table 4.

In order to obtain a curve of input and output volumes of the trench, a time interval between 10 and 30 minutes was used, this interval being varied every 5 minutes and, as result, it was obtained the data presented in Table 5.

Table 4 - Data for the dimensioning of the trench

\begin{tabular}{ll}
\hline \multicolumn{2}{c}{ Initial Calculations } \\
\hline Trench volume $\left(\mathrm{m}^{3}\right)$ & 15000 \\
\hline Percolation area $\left(\mathrm{m}^{2}\right)$ & 30005 \\
\hline
\end{tabular}

Tabela 5 - Data of the input and output volume curve of the trench

\begin{tabular}{cccccc}
\hline \multicolumn{5}{c}{ Affluent and exit volume curves of the trench } \\
\hline $\mathrm{t}(\mathrm{min})$ & $\mathrm{t}$ (hours) & $\mathrm{I}_{\mathrm{T}}(\mathrm{l} / \mathrm{s} / \mathrm{ha})$ & $\mathrm{Ve}\left(\mathrm{m}^{3}\right)$ & $\mathrm{Vs}\left(\mathrm{m}^{3}\right)$ & $\mathrm{Ve}-\mathrm{Vs}\left(\mathrm{m}^{3}\right)$ \\
\hline 10 & 0.17 & 308.98 & 2544.41 & 31.7753 & 2512.64 \\
\hline 15 & 0.25 & 257.49 & 3180.62 & 47.66294 & 3132.96 \\
\hline 20 & 0.33 & 222.48 & 3664.22 & 63.55059 & 3600.67 \\
\hline 25 & 0.42 & 196.93 & 4054.28 & 79.43824 & 3974.84 \\
\hline 30 & 0.50 & 177.35 & 4381.54 & 95.32589 & 4286.22 \\
\hline
\end{tabular}

The largest difference between the entrance and exit volumes of the trench (Ve Vs) was used to obtain the dimensioned volume value, dividing the maximum value of (Ve - Vs) by the porosity value of the filling material of the trench. Thus, a value for $V_{\text {dim }}$ equal to $14287.4 \mathrm{~m}^{3}$ was found, which approaches the VT value $\left(15000 \mathrm{~m}^{3}\right)$. So, it is possible to affirm that the dimensions of the infiltration trench necessary to penetrate the entire surface runoff of the area are $2.5 \mathrm{~m}$ high, $1 \mathrm{~m}$ wide and $6000 \mathrm{~m}$ long.

The calculations presented above were redone using a safety factor of 2 for the saturated hydraulic conductivity of the soil, as o make it equal to $1.765 \times 10^{-6} \mathrm{~m} / \mathrm{s}$. The other data used for the sizing remained the same. 
However, even with the use of the reduction factor, the area required for the infiltration trench remains the same as the trench area without the use of the safety factor in the sizing. This is because the soil hydraulic conductivity values are very small and therefore do not cause significant changes in the results found.

3.4 Analysis of the applicability of infiltration trenches at the first flooding point Marquês do Pombal Street

In order to verify if the dimensions of the infiltration trenches determined previously are possible to be applied in the study sites, some aspects were analyzed such as inclination of streets, width of walkways and conservation conditions, stock of poles, trees or some other type of vegetation and also, the existence of any obstacle that could prevent the application of the trench on the site.

In the area that contributes to the emergence of the flooding point on Marquês do Pombal Street, it was verified that due to large slopes of the streets, only two streets are suitable for the implantation of the infiltration trenches - Ernesto Alves Street and Primeiro de Maio Street.

Depending on the width of the walkways, the width of the trench should be 50 $\mathrm{cm}$ so that the trench is better suited to the location in question. There is no need to modify the height, so it remains $2.5 \mathrm{~m}$. On the other hand, adding up the spaces available for the implementation of the trench, there is a total of $810 \mathrm{~m}$ in length that is much smaller than the $6000 \mathrm{~m}$ that were initially estimated. Thus, the estimated dimensions at the beginning of the infiltration trench design would be for it to retain and penetrate all surface runoff; however this is not the goal of the implantation of this device. The application of the infiltration trench is aimed at reducing the surface runoff in order to avoid that the excess of the same, not supported by the conventional micro drainage system, causes flooding and disturbances for the population. Thus, the new dimensions of the infiltration trench at the first flooding point are presented in Table 6. 
Tabela 6 - Final dimensions of the infiltration trench

\begin{tabular}{lc}
\hline \multicolumn{2}{c}{ Estimated Dimensions } \\
\hline Length $(\mathrm{m})$ & 810 \\
\hline Width $(\mathrm{m})$ & 0.5 \\
\hline Height $(\mathrm{m})$ & 2.5 \\
\hline
\end{tabular}

3.5 Dimensioning and analysis of the applicability of infiltration trenches at the second flooding point - São Bento Avenue

In the dimensioning of the second flooding point, the only value that differs from the first point is the contribution area, which, in this case, is equal to 24.5 ha. The data obtained are shown in Table 7.

Table 7 - Trench dimension data

\begin{tabular}{lc}
\hline \multicolumn{2}{c}{ Data } \\
\hline Basin contribution area (ha) & 24.5 \\
\hline Flow coefficient & 0.6 \\
\hline $\begin{array}{l}\text { Saturated hydraulic } \\
\text { conductivity - } \mathrm{k}(\mathrm{m} / \mathrm{s})\end{array}$ & 0.00000353 \\
\hline Reduction Factor & 2 \\
\hline $\mathrm{k}$ reduced (m/s) & $1.765 \mathrm{E}-06$ \\
\hline Return period (years) & 5 \\
\hline Porosity & 0.3 \\
\hline
\end{tabular}

As before, the first dimensioning was performed without the use of the safety factor. The dimensions of the trench are shown in Table 8, the initial calculation of the dimensions of the trench is presented in Table 9 and in Table 10 the data of the curve of incoming and outgoing volumes of the infiltration device is visualized. 
Table 8 - Dimension of the trench

\begin{tabular}{lc}
\hline \multicolumn{2}{c}{ Estimated Dimensions } \\
\hline Length $(\mathrm{m})$ & 7800 \\
\hline Width $(\mathrm{m})$ & 1 \\
\hline Height $(\mathrm{m})$ & 2.5 \\
\hline
\end{tabular}

Table 9 - Data for dimensioning the trench

\begin{tabular}{lc}
\hline \multicolumn{2}{c}{ Initial Calculations } \\
\hline Trench volume $\left(\mathrm{m}^{3}\right)$ & 19500 \\
\hline Percolation area $\left(\mathrm{m}^{2}\right)$ & 39005 \\
\hline
\end{tabular}

Table 10 - Data of the input and output volume curve of the trench

\begin{tabular}{cccccc}
\hline \multicolumn{5}{c}{ Affluent and exit volume curves of the trench } \\
\hline $\mathrm{t}(\mathrm{min})$ & $\mathrm{t}$ (horas) & $\mathrm{I}_{\mathrm{T}}(\mathrm{l} / \mathrm{s} / \mathrm{ha})$ & $\mathrm{Ve}\left(\mathrm{m}^{3}\right)$ & $\mathrm{Vs}\left(\mathrm{m}^{3}\right)$ & $\mathrm{Ve}-\mathrm{Vs}\left(\mathrm{m}^{3}\right)$ \\
\hline 10 & 0.17 & 308.98 & 3406.46 & 41.3063 & 3365.15 \\
\hline 15 & 0.25 & 257.49 & 4258.21 & 61.95944 & 4196.25 \\
\hline 20 & 0.33 & 222.48 & 4905.65 & 82.61259 & 4823.04 \\
\hline 25 & 0.42 & 196.93 & 5427.87 & 103.2657 & 5324.60 \\
\hline 30 & 0.50 & 177.35 & 5866.00 & 123.9189 & 5742.08
\end{tabular}

The largest difference between the entrance and exit volumes of the trench was approximately $5742.08 \mathrm{~m}^{3}$, which was later divided by the porosity value of the fill material (0.3). Thus, the value obtained for the volume dimensioned was $19140.28 \mathrm{~m}^{3}$, which approaches the value of the volume of the trench that is $19500 \mathrm{~m}^{3}$. Therefore, the dimensions of the infiltration trench that would be required to penetrate the entire surface runoff of the area are $2.5 \mathrm{~m}$ high, $1 \mathrm{~m}$ wide and $7800 \mathrm{~m}$ long.

The sizing was redone using a safety factor of 2 for the saturated hydraulic conductivity of the soil, so that it started to present a value of $1.765 \times 10^{-6} \mathrm{~m} / \mathrm{s}$. The 
other parameters used for the sizing remained the same. Also, as previously noted, the use of the safety factor does not modify the area required for the implantation of the infiltration trench.

\subsection{Analysis of the applicability of infiltration trenches at the second flooding point -}

\section{São Bento Avenue}

In the area that contributes to the emergence of the second flooding point on São Bento Avenue, it was observed that several streets do not have sidewalks and others have very narrow walkways and vegetation growing in them, so these streets were discarded from the analysis of the viability of infiltration trenches.

The estimated dimensions for the infiltration trench at the second flooding point were $1 \mathrm{~m}$ wide, $2.5 \mathrm{~m}$ high and $7800 \mathrm{~m}$ long, but as in the previous case, depending on the width of the walkways, the width should be smaller so that the trench adapts to the study site, that is, $70 \mathrm{~cm}$. As for height, there is no need for it to be modified, remaining $2.5 \mathrm{~m}$. On the other hand, adding up the spaces available for the implementation of the trench, there is a total of $690 \mathrm{~m}$ in length - much smaller than the $7800 \mathrm{~m}$ initially estimated.

As in the first flooding point, the dimensions that were estimated at the beginning of the infiltration trench calculation would be for it to retain and penetrate all surface runoff, which is not the purpose of installing this device. Thus, the new dimensions of the infiltration trench at the second flooding point are shown in Table 11.

Table 11 - Final dimensions of the infiltration trench

\begin{tabular}{lc}
\hline \multicolumn{2}{c}{ Estimated Dimensions } \\
\hline Length $(\mathrm{m})$ & 690 \\
\hline Width $(\mathrm{m})$ & 0.7 \\
\hline Height $(\mathrm{m})$ & 2.5 \\
\hline
\end{tabular}




\subsection{Sizing of the Delayed Reservoirs}

Reservoirs that collect and reserve rainwater are source control devices that temporarily store surface runoff water in local reservoirs. In order to carry out its design, the city of Sao Paulo used "Piscininhas Law". The formula for determining the capacity of the reservoirs that collect and reserve rainwater is simple and the variables used in it, with the exception of the waterproofed area, are already established. Thus, the reservoir volume is found through Equation (1).

$V=0,15 \times A i \times I P \times t$

Where:

"V" is the volume of the reservoir $\left(\mathrm{m}^{3}\right)$, "Ai" is the waterproofed area $\left(\mathrm{m}^{2}\right)$, "IP" is the rainfall index being equal to $0.06 \mathrm{~m} / \mathrm{h}$ and " $\mathrm{t}$ " is the rain duration time ( 1 hour).

For the sizing of the reservoirs, a standard $12 \times 30 \mathrm{~m}$ plot was considered corresponding to an area of $360 \mathrm{~m}^{2}$. As each flooding point is located in different zones of urban occupation, according to the Master Plan of the municipality, the reservoirs were designed for $85 \%$ occupancy rates for Marquês do Pombal Street inserted in the Commercial and Services Zone 1 (ZCS 1), and 80\%, 60\% and 50\% for São Bento Avenue - inserted in the Commercial and Service Corridor 1 (CCS 1), Commercial and Service Corridor 2 (CCS 2) and Residential Zone 1 (ZR 1). Thus, the volumes of the reservoirs that collect and reserve rainwater found were $2.754 \mathrm{~m}^{3}$ for ZCS1 - Marquês do Pombal Street - $2.592 \mathrm{~m}^{3}$ for CCS1, $1.944 \mathrm{~m}^{3}$ for CCS2 and $1.62 \mathrm{~m}^{3}$ for ZR1, both on São Bento Avenue.

Therefore, the increase in concentration time due to reservoirs that collect and reserve rainwater using the Passo Fundo rainfall intensity equation was analyzed, with a 5-year return period and 5-minute concentration time. With these data, a precipitation value of $141.74 \mathrm{~mm} / \mathrm{h}$ was reached.

For the determination of the flow rate of the reservoirs that collect and reserve rainwater, the Rational Method was used, equation 16, with water outflow coefficient of 0.6 and the same areas used in the calculation of the volumes of the reservoirs. 
Subsequently, it becomes possible to calculate the filling time of the same determined by dividing the volume of the reservoir by the flow rate of the same. The results are shown in Table 12.

Table 12 - Data obtained according to the occupation zones for the dimensioning of the delay reservoirs

\begin{tabular}{cccccc}
\hline $\begin{array}{c}\text { Occupation } \\
\text { zone }\end{array}$ & $\begin{array}{c}\text { Flow rate } \\
(\mathrm{L} / \mathrm{s})\end{array}$ & $\begin{array}{c}\text { Reservoir } \\
\text { volume }\left(\mathrm{m}^{3}\right)\end{array}$ & $\begin{array}{c}\text { Reservoir } \\
\text { volume }(\mathrm{L})\end{array}$ & $\begin{array}{c}\text { Filling time } \\
(\mathbf{s})\end{array}$ & $\begin{array}{c}\text { Filling } \\
\text { time (min) }\end{array}$ \\
\hline ZCS 1 & 7.23 & 2.754 & 2754 & 380.91 & 6.349 \\
\hline CCS 1 & 6.8 & 2.592 & 2592 & 381.18 & 6.353 \\
\hline CCS 2 & 5.1 & 1.944 & 1944 & 381.18 & 6.353 \\
\hline ZR 1 & 4.25 & 1.620 & 1620 & 381.18 & 6.353 \\
\hline
\end{tabular}

As the filling time values for the reservoirs to collect and reserve rainwater are very close, it was possible to verify that, in all the zones of occupation, the filling time of the reservoirs is equal to 6.35 minutes.

\subsection{Comparison of conventional and unconventional drainage systems}

The comparison between conventional and unconventional drainage systems was performed by means of graphs and the plot of the direct surface flow unit hydrograms. Figure 6 shows the comparison between flow rates, in $\mathrm{m}^{3} / \mathrm{s}$, at the first flooding point on Marquês do Pombal Street and at the second flood point on São Bento Avenue.

Figure 6 - Comparison charts between flow rates at flooding points

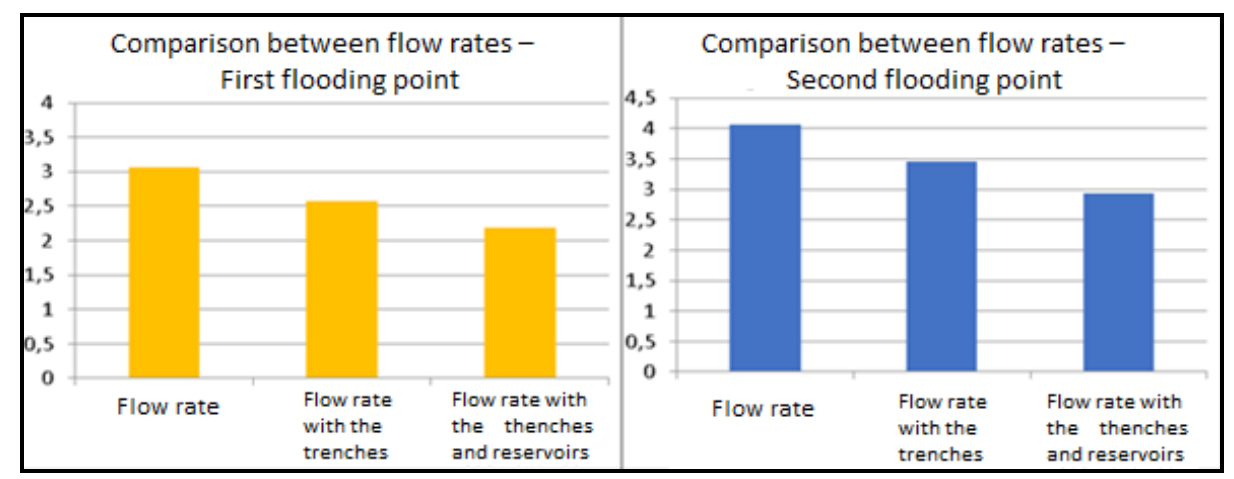

Source: Own elaboration (2016) 
Furthermore, the direct surface flow hydrograms were drawn for a time equal to one hour. In Figure 7, the hydrograms are shown for the one hour interval referring to the first and second flooding points. Both hydrographs present the flow rates for the three distinct hypotheses - the first hypothesis considers the concentration time found for each area plus 5 minutes which is the average time that leads to the water falling on the roofs to flow to the ground, the second hypothesis considers the time of filling of the trenches added to the time of the previous hypothesis, while the third hypothesis considers all the times previously mentioned added to the time of filling of the reservoirs that collect and reserve rainwater.

Figure 7 - Hydrographs of flooding points

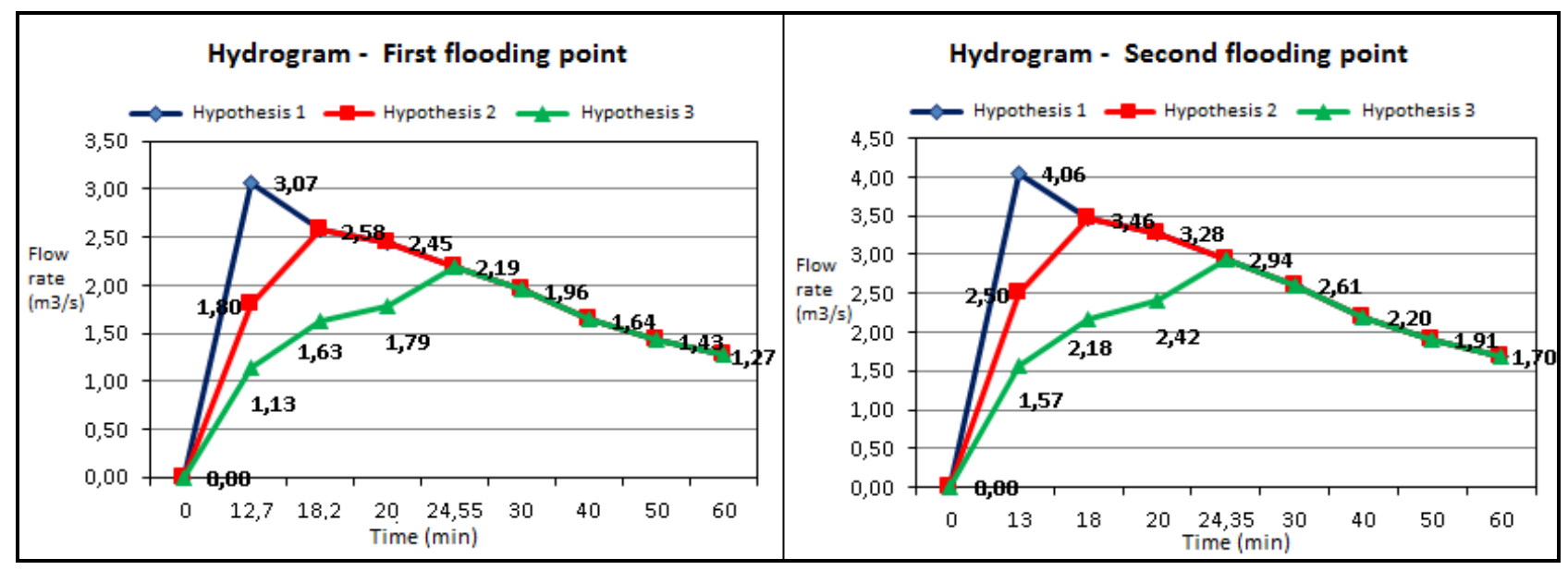

Source: Own elaboration (2016)

Analyzing the graphs of Figure 6 , it is possible to detect a significant reduction of flow rate by comparing the value in the first flooding point under study with the conventional micro drainage system only to the flow results obtained through the implementation of the unconventional control measures. The reduction in flow with the implementation of the infiltration trenches is approximately $16 \%$ and when considering the trenches and the reservoirs that collect and reserve rainwater, this reduction reaches almost 29\%. In addition, a significant reduction in flow rate is observed by comparing the value of only the conventional micro drainage system that exists in the second flooding area under study with the flow rate results obtained 
through the implementation of the unconventional control measures. The reduction in flow rate with the implementation of the infiltration trenches is almost $15 \%$ and when considering the trenches and the reservoirs that collect and reserve rainwater, this reduction reaches approximately $27.5 \%$.

With regard to Figure 7, the rise time of the hydrograms varies according to each hypothesis. Nevertheless, it is important to note that with the implementation of unconventional drainage control measures, such as infiltration trenches and reservoirs that collect and reserve rainwater, the hydrograph concentration times increase and the flow spikes decrease, resulting to a better distributed surface runoff over time and, thus, avoiding the emergence of flooding points.

\section{Final Considerations}

The floods in the municipalities are due to uncontrolled urban occupation and without planning, thus causing the waterproofing of large areas and generating exacerbated surface runoff since the water cannot penetrate the soil. Another cause of flooding in cities is the design of the drainage system, which currently does not seek to solve the problem, but rather to transfer it to a downstream point. It results in systems that seek to drain water as quickly as possible and that lead the excess of surface runoff to another place without worrying about the volume drained.

Therefore, the control of drainage at the source emerged as an alternative to solve the problem, based on techniques such as infiltration and the reservation of excess surface runoff, described in drainage manuals of municipalities

In the diagnosis of the micro drainage system in the study, for the sites located in the municipality of Carazinho, there was no maintenance of this system. Some street inlets here were extremely precarious conditions and others partially obstructed by residues solids. Furthermore, gutters, when present, were also in poor condition. The height of the curb in the areas of contribution of the points under study varied, having in some points heights between 10 and $12 \mathrm{~cm}$ and in others $20 \mathrm{~cm}$, this being a value considered high for a curb height. 
Regarding the implantation of the trenches, not many sidewalks were found in the municipality with adequate conditions so that these could be implemented, either by the great slope of the streets, by the width or nonexistence of the walkways. However, it is important to emphasize that this measure reduced the flow rate in a considerable way, for the first flooding point was reduced by $16 \%$ and in the second flooding point by $15 \%$.

The use of the delayed reservoirs, along with the infiltration trenches, provided an even bigger decrease in the flow at the flooding points. Consequently, concentration times at these sites also increased with the use of unconventional control measures. The calculated concentration time for the contribution areas without the infiltration and delay devices were 12.7 and 13 minutes for the first and second flooding point respectively. With the infiltration trenches, the times passed to 18.2 and 18 minutes, accounting an increase of $43 \%$ and $38.5 \%$ in each case. The total increase in concentration time with trenches and delay reservoirs was 93\% at the first flooding point and $87 \%$ at the second flooding point.

Therefore, the implantation of the unconventional measures, as a matter of fact, practically doubles the time of concentration of the surface runoff, generating considerable reductions in the flow peak in each contribution area.

Thus, it is recommended to use unconventional drainage control measures along with the conventional micro drainage systems in order to reduce excess runoff. To do this, however, there must be carried a more profound analysis at the place where the control device is planned, in order to determine which type of measure will be more adequate according to the existing conditions in each place, highlighting the interference with urban water and sewage systems. Finally, it is essential to emphasize that, in addition to decreasing peak flows and reducing flooding problems, these control measures are sustainable and more convenient for the urban environment, as far as socio-environmental issues are concerned. 


\section{References}

CAPUTO, Ú. K.. Avaliação do Potencial de Utilização de Trincheiras de Infiltração em Espaços com Urbanização Consolidada. 2012. Dissertação (Programa de Pós Graduação em Saneamento, Meio Ambiente e Recursos Hídricos). Universidade Federal de Minas Gerais, Belo Horizonte.

DAMIÃO, M.; FELDON, A.; MUKAl, G.; ROSA, A.; UECHI, M. Lei das Piscininhas. Universidade de São Paulo, 2010.

PINHEIRO, S. A.; PINTO, L. H. Orientações Básicas para Drenagem Urbana. Belo Horizonte, $2006 . \quad$ Disponível em: http://www.feam.br/images/stories/arquivos/Cartilha\%20Drenagem.pdf. Acesso em 03 ago. 2016.

PINTO, L. H.; PINHEIRO, S. A.. Orientações básicas para drenagem urbana. Belo Horizonte, 2006.

PONTE et al. 2014. Urbanização e drenagem urbana: concepções divergentes na Bacia da Estrada Nova, Belém-PA. 3 Seminário sobre o Tratamento de Áreas de Preservação Permanente em Meio Urbano e Restrições Ambientais ao Parcelamento do Solo, p. 3.

PREFEITURA MUNICIPAL DE PORTO ALEGRE. Departamento de Esgotos Pluviais. Plano Diretor de Drenagem Urbana: Manual de Drenagem Urbana. Volume VI. Porto Alegre, 2005.

SILVA, J. P.. Estudos Preliminares para Implantação de Trincheiras de Infiltração. 2007. Dissertação de Mestrado da Universidade de Brasília. Distrito Federal.

TRINDADE, S. Subsídios para implantação de trincheiras de infiltração na área urbana de Rio Claro/SP. 2009. Trabalho de Conclusão de Curso (Curso de Engenharia Ambiental), Instituto de Geociências e Ciências Exatas - Unesp, Rio Claro. 